\title{
Anti-inflammatory Effect of Galium aparine Extract in RAW 264.7 Cells
}

\author{
Joong Hyun Shim \\ Faculty of Cosmetics and Beauty Biotechnology, Semyung University, Jecheon-si, Chungcheongbuk-do, Korea
}

Corresponding author: Joong Hyun Shim, Faculty of Cosmetics and Beauty Biotechnology, Semyung University, 65 Semyung-ro, Jecheonsi, Chungcheongbuk-do 27136, Korea

Tel.: +82436491615

Fax: +82 436491730

Email: jhshim@semyung.ac.kr

Received November 8, 2017

Revised February 2, 2018

Accepted February 20, 2018

Published June 30, 2018

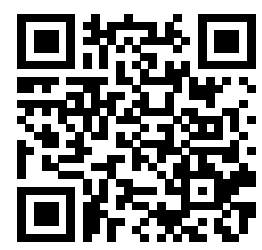

\begin{abstract}
Purpose: This study was performed to identify the skin anti-inflammatory effect of Galium aparine (GA) extract on RAW 264.7 cells. Methods: To investigate antiinflammatory effects of GA on RAW 264.7 cells, we measured 1,1-Diphenyl-2picrylhydrazyl (DPPH) radical scavenging activity, cell viability, mRNA expressions, nitric oxide (NO), and prostaglandin E2 (PGE2) production. Results: In this study, we elucidated anti-inflammatory effects of GA extract on interleukin $1 \alpha(I L 1 \alpha)$, interleukin $1 \beta(I L 1 \beta)$ interleukin 6 (IL6), and tumor necrosis factor $\alpha(T N F \alpha)$ mRNA expression and NO production. Quantitative real-time polymerase chain reaction (qRT-PCR) showed that the GA extract decreased mRNA expression level of $I L 1 \alpha$, $I L 1 \beta$, ILG, and TNF $\alpha$ and detection of NO and PGE2 also revealed that GA induces anti-inflammatory effects. Conclusion: Therefore, we successfully identified the anti-inflammatory effect of GA extract, and this result showed that the GA extract can be a potent cosmetic ingredient for anti-inflammatory and atopic dermatitis. Based on this, we anticipate further studies on the GA extract to determine a mechanism for developing not only cosmetics but also healthcare food or medicines.
\end{abstract}

Keywords: Galium aparine, Radical scavenging, Anti-inflammatory, Nitric oxide, PGE2

\section{Introduction}

피부는 신체의 항상성을 유지시키기 위하여 외부 요인으로부 터 보호하는 중요한 보호 장벽이다. 피부는 화학적, 물리적 및 생물학적 장벽 기능을 수행하지만 다양한 외부 환경 요인과 접촉 하기 때문에 손상 받기 쉬운 조직이다(Lee et al., 2007; Yoon et al., 2013). 주요 외부 스트레스 요인은 자외선, 오염 물질, 미세 분진 및 미생물의 증식이다. 이러한 외부 스트레스에 의한 면역 조절 이상으로 인해 피부 염증 및 아토피성 피부염 및 천 식과 같은 만성 질환이 증가하고 있는 추세이다(Heinzmann et al., 2002; Sung et al., 2012).

염증은 다양한 유형의 감염이나 대사 물질에 의한 자극에 의해 생성되는 방어 기작이다. 염증은 염증 매개체를 분비하는 염증 세포인 대식세포에 의해 활성화된다. 염증 세포는 몸의 모든 조 직에 분포하며 선천성 면역 반응을 담당하고 대식세포에 의해 추 가적인 면역 반응이 유발된다. 대식세포는 아토피성 피부염, 천
식, 기관지염, 다발성 경화증, 관절염 등과 뇌졸중, 파킨슨병 또 는 알츠하이머 병과 같은 퇴행성 뇌질환과 같은 질환을 일으키고 악화시키기도 한다(Albina \& Reichner, 1995).

대식세포는 단핵세포로부터 분화된 세포로 염증반응에서 일차 적 방어 역할을 담당한다. Lipopolysaccharide (LPS)는 대식세 포가 지닌 Toll-like receptor (TLR)을 자극하여 세포 내 신호 전달경로인 mitogen-activated protein kinase (MAPK)의 활 성화를 유도하고, 이는 TNF $\alpha$, IL1, IL6와 같은 염증성 사이토 카인을 증가시키며, $\mathrm{NO}, \mathrm{PGE} 2$ 와 같은 염증성 매개인자를 분비 한다(Akira \& Takeda, 2004; Gomez et al., 2005). 이렇게 생 성된 염증성 매개인자들은 주변세포의 면역기능을 활성화시키는 중요한 역할을 하기도 하지만 과량의 $\mathrm{PGE} 2$ 와 $\mathrm{NO}$ 등은 질병 악 화의 원인이 되기도 한다(Kim et al., 2004). NO는 염증의 대표 적 지표물질로, 일반적인 $\mathrm{NO}$ 는 박테리아와 같은 미생물을 죽이 거나 종양을 억제하는 중요한 역할을 하지만 염증에서의 과도한 $\mathrm{NO}$ 는 조직손상, 유전적 변이 및 신경손상을 유발한다(Gabay, 
2006; Im, 2014; Lee et al., 2014; Van Triel et al., 2010). 또한 cyclooxygenase 2 (COX2)는 arachidonic acid로부터 염 증매개물질인 PGE2 생성을 유도하는 효소로서 iNOS와 함께 염 증반응에 중요한 역할을 담당한다. LPS에 의한 대식세포가 활성 시 $\mathrm{NO}$ 와 $\mathrm{PGE} 2$ 는 IL1 및 $\mathrm{TNF} \alpha$ 와 같은 염증성 사이토카인 등 을 생산한다(Horwood et al., 2006; Hirohashi et al., 1996). 따라서 $\mathrm{NO}$ 의 생성이나 PGE2, 염증성 사이토카인의 발현억제는 염증성 질환을 치료하거나 예방에 있어서 중요한 목표가 된다.

갈퀴덩굴(Galium aparine, GA)은 꼭두서니과에 속하는 일년 생 혹은 다년생 초본성 식물로 북아메리카, 유럽 및 아시아에 이 르기까지 넓은 지역에서 서식한다(Jeong \& Pak, 2009). GA의 추출물은 주로 차로 사용되고, 본 식물의 활성 성분은 주로 천연 항산화 물질로 알려진 iridoids, anthraquinones, flavonoids, alkanes, polyphenolic acids 및 ascorbic acid 이다(Bokhari et al., 2013). GA는 림프 부종, 편도선염, 황달, 상처, 암, 발 열, 괴혈병, 고혈압 및 백혈병 치료에 사용되어지는 식물이다 (Ahmad \& Javed, 2007; Ergun et al., 1999; Orhan et al., 2012). 또한 일부 GA 종은 유럽과 북아메리카에서 궤양 또는 유 방암 치료에 전통적으로 사용되어 왔다(Hartwell, 1971). 하지 만 GA가 RAW 264.7 대식세포의 염증 완화에 효과적인지에 대 한 연구는 없다. 따라서 본 연구에서는 LPS에 의해 자극이 유발 된 RAW 264.7 대식세포에 GA 추출물의 항염증 효과를 확인하 였다.

\section{Methods}

\section{1. $\mathrm{GA}$ 의 추출, 농축, 건조과정}

GA 분말은 STARWEST (USA)로부터 구입하였으며, $100 \mathrm{~g}$ 의 $\mathrm{GA}$ 분말을 $900 \mathrm{~mL}$ 의 $95 \%$ 에탄올을 가하고, $70-80^{\circ} \mathrm{C}$ 에서 한 시간씩 3회 환류추출(DH.WEB01004; DAIHAN, Korea)을 실시하였다. 추출물 여과는 $5 \mu \mathrm{m}$ 의 막공 크기를 가지는 filter paper (filter paper No. 2; Adventec, Japan)를 이용하여 감 압 여과하였다. 여과액은 rotary vacuum evaporator (CCA1110 ; EYELA, Japan)을 이용하여 감압 농축하여 $16.8 \mathrm{~g}$ 의 분 말을 수확하였다. 이후 수확된 GA 분말은 $1: 1$ 비율의 hexane (Sigma-Aldrich, USA)과 물의 혼합액으로 분획하여 $900 \mathrm{~mL}$ 의 물 분획물을 수확하였다. 물 분획물은 freeze dryer (FDU1200 ; EYELA, Japan)를 사용하여 $-45^{\circ} \mathrm{C}$ 동결 건조하여 8.5 $\mathrm{g}$ 의 건조 분말을 본 실험에 사용하였다.

\section{2. 세포배양}

RAW 264.7 대식세포는 한국세포주은행(Korean Cell Line Bank, Korea)에서 구입하여 사용하였다. Fetal bovine serum
(FBS; Welgene, Korea)와 penicillin/streptomycin (Welgene) 이 첨가된 Dulbecco's modified Eagle's medium (DMEM; Invitrogen, USA)을 세포배양에 사용했다. RAW 264.7 대식세 포는 $37^{\circ} \mathrm{C}, 5 \% \mathrm{CO}_{2}, 100 \%$ 습도 조건의 인큐베이터에서 배양하 였다.

\section{DPPH radical 소거능 분석}

1,1-Diphenyl-2-picrylhydrazyl (DPPH; SigmaAldrich) radical 소거능 평가를 위해 $\mathrm{DPPH}$ 를 $\mathrm{MeOH}$ (SigmaAldrich):water (3:2)에 $0.1 \mathrm{mM}$ 의 농도로 녹여 사용하였 다. $\mathrm{DPPH}$ 용액 $500 \mu \mathrm{L}$ 에 시료 $50 \mu \mathrm{L}$ 를 넣고 실온에서 30 min 동안 반응시킨 후 ELISA reader $\left(\operatorname{Epoch}^{\mathrm{TM}}\right.$; BioTek ${ }^{\circledR}$ Instruments, USA)로 $517 \mathrm{~nm}$ 의 파장에서 흡광도를 측정하였 다. $\mathrm{DPPH}$ 소거능은 시료 무첨가군과 시료 첨가군 사이의 흡광 도 차이를 백분율로 나타내었다.

\section{4. 세포 생존율 검증}

세포 생존율은 cell counting kit-8 (CCK-8; Abbkine Scientific, China)를 사용하여 측정하였다. RAW 264.7 대식 세포를 조직 배양 접시에 접종하고 $24 \mathrm{~h}$ 동안 $\mathrm{GA}$ 추출물로 처 리하였다. 이후 CCK-8 시약을 phenol-red가 들어있지 않은 $\mathrm{DMEM}$ 에 $1 / 10$ 로 희석하여 $5 \% \mathrm{CO}_{2}, 37^{\circ} \mathrm{C}$ 에서 $1 \mathrm{~h}$ 동안 처리하 였다. ELISA reader를 이용하여 $450 \mathrm{~nm}$ 에서 흡광도를 측정하 고, 세포가 첨가되지 않은 대조군의 흡광도를 기초로 하여 세포 생존율을 산출하였다. 세포의 생존율은 대조군에 대한 백분율로 표기하였다.

\section{5. 실시간 유전자 중합효소 연쇄반응(qRT-PCR)}

Invitrogen사의 TRIzol Reagent를 사용하여 RNA를 추출 하였다. 추출한 RNA로부터 cDNA의 합성은 ReverTra Ace ${ }^{\circledR}$ reverse transcription kit (Toyobo, Japan)를 사용하여 합성하 였으며, RAW 264.7 대식세포 표지인자의 발현을 비교 측정하 기 위하여 StepOnePlusTM Real-Time PCR System (Applied Biosystems, USA)을 사용하여 진행하였다. 실험에 사용된 TaqMan ${ }^{\circledR}$ Gene Expression Assay (Applied Biosystems)는 Table 1 과 같다.

\section{PGE2 생성량 측정}

$\mathrm{GA}$ 추출물이 PGE2의 생성에 미치는 영향을 알아보기 위하여 RAW 264.7 대식세포를 $24 \mathrm{~h}$ 동안 인큐베이터에서 전 배양한 후, $100 \mathrm{ng} / \mathrm{mL}$ lipopolysaccharides (LPS, Sigma-Aldrich) 와 $\mathrm{GA}$ 추출물을 첨가하여 $6 \mathrm{~h}$ 동안 배양하였다. $\mathrm{PGE} 2-$ ELISA (enzyme-linked immunosorbent assay) kit (Pierce Endogens, USA)를 이용하여 제조사의 프로토콜을 따라 RAW 


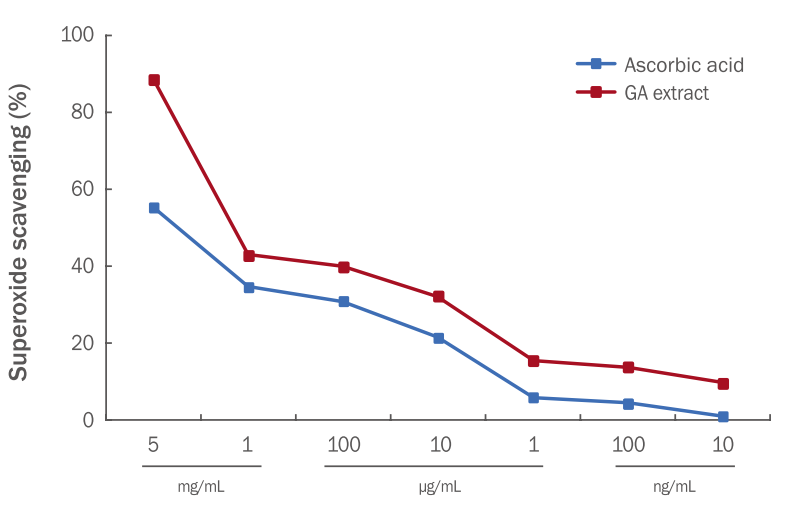

Figure 1. DPPH radical scavenging activity of GA extracts.

Anti-oxidant ability of GA extracts was measured by the DPPH assay at indicated concentrations. GA extracts had free radical scavenging effects that were similar to those of ascorbic acid, which was used as a positive control. GA, Galium aparine; DPPH, 1,1-Diphenyl-2-picrylhydrazyl.

\section{NO 정량}

RAW 264.7 대식세포를 $35 \mathrm{~mm}$ 배양접시에 $30 \times 10^{4}$ cells/ well로 분주하고 $24 \mathrm{~h}$ 동안 전 배양한 후, $100 \mathrm{ng} / \mathrm{mL} \mathrm{LPS}$ 와 GA 추출물을 첨가하여 $24 \mathrm{~h}$ 동안 배양 후, 배양액을 수집하 여 원심 분리한 후 상등액 $100 \mu \mathrm{L}$ 를 사용하여 $\mathrm{NO}$ 의 생성량을 $\mathrm{NO}$ detection kit (iNtRON, Korea)를 사용하여 제조사의 프 로토콜을 따라 측정하였다. 상등액 $100 \mu \mathrm{L}$ 에 $50 \mu \mathrm{L}$ 의 N1 버퍼 $(\mathrm{iNtRON})$ 를 첨가하여 $10 \mathrm{~min}$ 간 상온에 반응시키고 $\mathrm{N} 2$ 버퍼 (iNtRON)를 $50 \mu \mathrm{L}$ 추가하여 $10 \mathrm{~min}$ 간 반응시킨 후 520-560 $\mathrm{nm}$ 의 파장에서 ELISA reader로 흡광도를 측정하였다.

\section{8. 통계분석}

통계처리는 Student's $t$-test방법을 이용하여 유의수준을 0.05 ( $p<0.05)$ 로 하여 검정하였다.

\section{Results and Discussion}

\section{GA 추출물의 DPPH radical 소거능}

체내 활성산소는 지질, 단백질 등과 반응하여 노화를 유도할 수 있는 물질로, 이러한 활성산소를 제거할 수 있는 소재에 대한 연구가 활발하게 진행되고 있다. 특히 본 실험에 사용한 $\mathrm{DPPH}$ 는 항산화제의 radical 소거능을 평가하는데 주로 사용된다. GA 추출 물을 $5 \mathrm{mg} / \mathrm{mL}$ 에서 $10 \mathrm{ng} / \mathrm{mL}$ 의 농도로 연속 희석하여 radical 소거능을 측정하였다. 활성산소종의 과도한 생성은 노화나 암 등 의 질환을 유발하며, 활성산소종은 피부 광노화에 있어 중요한 역 할을 하는 것으로 알려져 있다(Pryor, 1982). 전자공여능에 이용 되는 $\mathrm{DPPH}$ 는 상대적으로 안정한 radical로서 전자를 공여 받으 면 자체의 자색이 엷어지고 황색을 띄게 된다. 본 연구에서 GA 추 출물에 대한 전자공여능을 확인한 결과, 농도 의존적으로 $\mathrm{DPPH}$ radical 소거능이 증가하였으며, 특별히 $5 \mathrm{mg} / \mathrm{mL}$ 과 $1 \mathrm{mg} / \mathrm{mL}$ 의 GA 추출물 처리시 양성대조군으로 사용한 ascorbic acid와 유사 한 항산화 효과를 지님을 확인하였다(Figure 1). 본 연구에서 사용 된 GA는 플라보노이드 배당체, 폴리페놀류, 탄닌, iridoids, 비타 민 C 등과 같은 다양한 항산화 물질과 다당체, 환원당, 유기산, 엽 록소 등이 함유되어 있는 소재로 요거트와 치즈 등과 같은 유제품 제조 등으로 사용되는 식물로 알려져 있다(Bokhari et al., 2013; Ergun et al., 1999). GA에 함유된 풍부한 항산화 물질에 의한 항 산화 효과는 Bokhari et al. (2013)의 보고와 일치하였다.

\section{GA 추출물의 농도별 RAW 264.7 대식세포의 생존율 분석}

본 연구에서 사용된 RAW 264.7 대식세포는 마우스 유래 대 식세포주이며, LPS에 의해 염증반응이 활성화되어 염증성 사이 토카인을 방출하는 것으로 알려져 있다. 대식세포는 인체 전반 에 분포하고 있으며 염증성 인자에 즉각적인 방어를 제공하는 면 역세포이며, 후천성 면역을 유도하는 항원제시 세포로서의 역할

Table 1. Gene name and assay ID number in qRT-PCR analysis

\begin{tabular}{llc}
\hline Symbol & Gene name & Assay ID \\
NOS2 & Nitric oxide synthase 2, inducible & Mm00440502_m1 \\
COX2 & Cyclooxygenase 2 & Mm03294838_g1 \\
IL1 $\alpha$ & Interleukin 1 alpha & Mm00439620_m1 \\
IL1 $\beta$ & Interleukin 1 beta & Mm00434228_m1 \\
IL6 & Interleukin 6 & Mm00446190_m1 \\
TNF $\alpha$ & Tumor necrosis factor alpha & Mm00443258_m1 \\
GAPDH & Glyceraldehyde-3-phosphate dehydrogenase & Mm99999915_g1 \\
\hline
\end{tabular}

qRT-PCR, quantitative real-time polymerase chain reaction. 


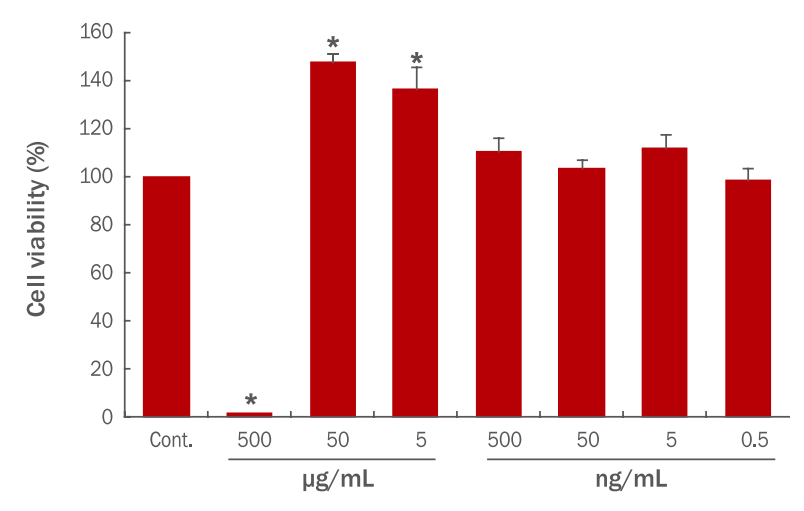

Figure 2. Cytotoxicity of GA extracts in RAW 264.7 cells.

RAW 264.7 cells $\left(4 \times 10^{3}\right.$ cells/well) were seeded in a 96-well tissue culture plate and treated with GA extracts for $24 \mathrm{~h}$. Cell viability was measured using the CCK-8 solution. Cell viability was the greatest when treated with $50 \mu \mathrm{g} / \mathrm{mL}$ of GA extract compared with that of the untreated control. These results are presented as the $\mathrm{M} \pm \mathrm{S}$.D. of the percentage of control optical density in triplicate. GA, Galium aparine; * $p<0.05$ compared with control group; Cont, Control; M $\mathrm{IS}$.D., means \pm standard deviations.

및 다양한 사이토카인을 분비하는 세포이다(Lawrence et al., 2002). GA 추출물의 항염증 효능을 확인하기에 앞서 연구에 사 용하고자 하는 GA 추출물의 독성여부를 확인하기 위하여 CCK8 assay를 수행하였다. 대조군은 시료로 처리하지 않았고 실험 군은 RAW 264.7 대식세포에 GA 추출물 $500,50,5 \mu \mathrm{g} / \mathrm{mL}$, $500,50,5,0.5 \mathrm{ng} / \mathrm{mL}$ 의 농도로 처리하여 세포 생존율을 측정 하였다(Figure 2). $500 \mu \mathrm{g} / \mathrm{mL}$ 이상의 농도에서 RAW 264.7 대 식세포의 생존율이 유의성 있게 감소하였고, $50 \mu \mathrm{g} / \mathrm{mL}$ 의 농도 로 처리시에는 RAW 264.7 대식세포의 생존율이 대조군에 비교
하여 유의성 있게 증가하여 세포 생존율을 저하시키지 않는 것 으로 판단하여 본 실험에서는 $5,25,50 \mu \mathrm{g} / \mathrm{mL}$ 의 GA 추출물을 처리하여 추가실험을 진행하였다.

\section{GA 추출물이 NO 생성에 미치는 영향}

체내에서 $\mathrm{NO}$ 는 세균과 종양을 제거하고 신경전달을 매개하거 나 혈압을 조절하는 등 다양한 역할을 담당하는 중요한 인자로 알려져 있다(Lee et al., 2014). 그러나 높은 수준으로 생성되는 $\mathrm{NO}$ 는 조직과 신경 손상을 유발하고, 유전자 변이를 유도하거나, 부종을 유발하는 등 과도한 염증반응을 일으킨다(Gabay et al., 2006; Im, 2014, Van Triel et al., 2010). 본 연구에서 GA 추 출물의 $\mathrm{NO}$ 감소 효능을 확인한 결과, LPS에 의해 $8 \mu \mathrm{M}$ 농도로 생성된 NO가 $50,25 \mu \mathrm{g} / \mathrm{mL}$ 의 GA 추출물을 처리하였을 때 각 각 $2.29,2.39 \mu \mathrm{M}$ 로 나타나, LPS 처리군에 비해 $\mathrm{NO}$ 생성이 감 소한 것으로 나타났다(Figure $3 \mathrm{~A})$.

LPS는 대식세포에서 iNOS라는 염증매개 인자의 생성을 촉진 하여 NO의 생성을 증가시킨다(Namazi, 2004). 따라서 $\mathrm{NO}$ 를 증가시키는 효소인 iNOS 유전자 발현을 GA 추출물이 감소시키 는지 확인하고자 qRT-PCR을 수행하였다. iNOS의 발현이 LPS 처리군에서 현저히 증가하였으나 $50,25 \mu \mathrm{g} / \mathrm{mL}$ 의 $\mathrm{GA}$ 추출물 을 처리한 세포주에서는 유의성 있게 감소하였다(Figure 3B).

\section{GA 추출물이 PGE2의 생성에 미치는 영향}

Prostaglandin (PG)는 arachidonic acid로부터 유래한 불 포화지방산으로 염증반응을 유도하는 호르몬으로 알려져 있다 (Yun et al., 2008). PG의 한 종류인 PGE2는 염증반응에 깊 이 관여하고, $\mathrm{COX} 2$ 유전자에 의하여 생성된다. $\mathrm{COX} 2$ 가 과발현

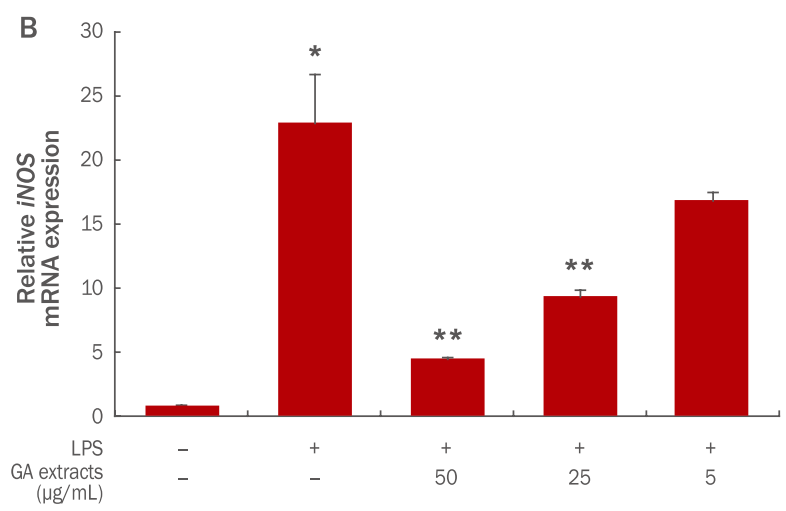

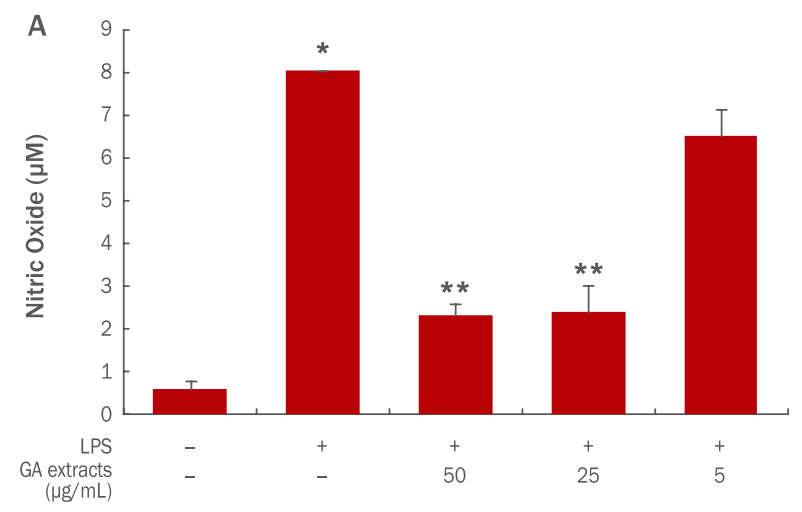

Figure 3. Effects of GA on NO production in LPS-stimulated RAW 264.7 cells.

RAW 264.7 cells were seeded in 35-mm culture dish and treated with GA for $24 \mathrm{~h}$. The medium was collected and analyzed using a NO detection kit. NO production under 50 and $25 \mu \mathrm{g} / \mathrm{mL}$ of GA extract was significantly decreased compared with that under LPS-treatment (A). Real-time RT-PCR analysis of the level of iNOS. The level of iNOS mRNA expression under 50 and $25 \mu \mathrm{g} / \mathrm{mL}$ of GA extract was significantly decreased compared with that under LPS-treatment (B). Data represent the M \pm S.D. of three independent experiments. GA, Galium aparine; NO, nitric oxide; LPS, lipopolysaccharide; " $p<0.05$ compared with control; ${ }^{* *} p<0.05$ compared with LPS-treated group; Cont, Control; M \pm S.D., means \pm standard deviations. 

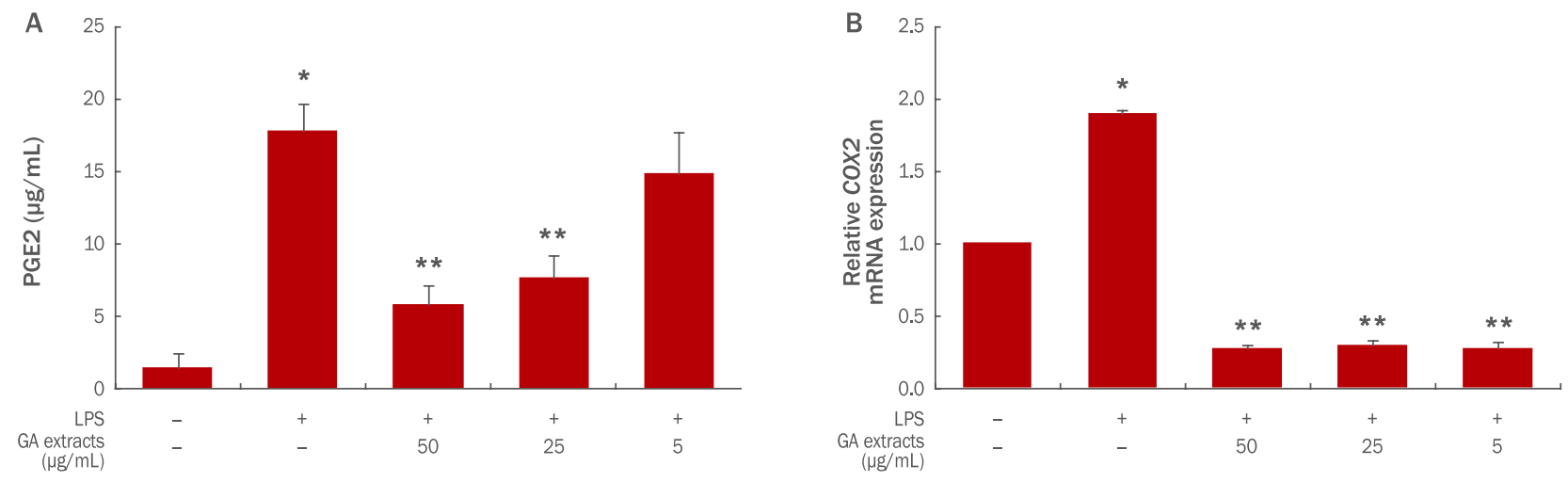

Figure 4. Effects of GA on PGE2 production in LPS-stimulated RAW 264.7 cells.

RAW 264.7 cells were seeded in a $35 \mathrm{~mm}$ tissue culture dish and treated with GA for $24 \mathrm{~h}$. The medium was collected and analyzed using PGE2-ELISA. PGE2 production under 50 and $25 \mu \mathrm{g} / \mathrm{mL}$ of GA extract was significantly decreased compared with that under LPS-treatment (A). Real-time PCR analysis of COX2. COX2 mRNA expression level under 50, 25, and $5 \mu \mathrm{g} / \mathrm{mL}$ of GA extract was significantly decreased compared with that under LPS-treatment (B). Data represent the M \pm S.D. of three independent experiments. PGE2, prostaglandin E2, GA, Galium aparine; LPS, lipopolysaccharide; COX2, cyclooxygenase 2; ELISA, enzyme-linked immunosorbent assay; Real-time PCR, realtime polymerase chain reaction; ${ }^{*} p<0.05$ compared with control; ${ }^{* *} p<0.05$ compared with LPS-treated group; Cont, Control; M \pm S.D., means \pm standard deviations.

할 경우에는 과생성된 $\mathrm{PGE} 2$ 에 의하여 통증, 발열 및 염증반응 이 유발된다(Harris et al., 2002; Namazi, 2004). GA 추출물 의 PGE2 감소 효능을 확인한 결과, LPS 처리군은 $17.9 \mu \mathrm{g} / \mathrm{mL}$ 의 생성을 나타냈으며, 그에 비해 $50,25 \mu \mathrm{g} / \mathrm{mL}$ 의 GA 추출물 을 처리하였을 때 각각 $5.8,7.6 \mu \mathrm{g} / \mathrm{mL}$ 로 나타나 LPS 처리군에 비해 PGE2 생성이 감소한 것으로 나타났다(Figure 4A). COX2 유전자의 발현은 LPS 처리군에서 1.9 배 증가하였으나 50,25 , $5 \mu \mathrm{g} / \mathrm{mL}$ 의 GA 추출물을 처리한 세포주에서는 유의성 있게 감 소하였다(Figure 4B).

\section{GA 추출물이 염증성 사이토카인의 생성에 미치는 영향}

피부에서 나타나는 만성적인 염증은 피부질환 뿐 아니라 피부 노화를 촉진시키는 인자가 된다(Lee et al., 2014; Noman et al., 2009; Shon et al., 2013). IL1 $\alpha$ 와 IL1ß는 다양한 면역반 응, 염증과정 및 조혈에 관여하는 사이토카인으로 활성화된 대식 세포와 면역반응이 유도된 $\mathrm{B}$ 림프구 및 섬유아세포 등에서 생성 되는 염증의 강력한 매개체이다(Ban et al., 2011; Lord et al., 1991). 특별히 IL1ß는 염증부위에 림프구와 호중구 등의 염증 세포의 침윤을 상승시키는 사이토카인이다(Baek et al., 2012; Roitt et al., 2001). IL6는 B 림프구의 성장과 분화를 유도하고, 알러지를 포함한 만성적 염증성 질환을 유발한다고 알려져 있다 (Gabay et al., 2006; Lee et al., 2014). 또한, TNFa는 염증 초기에 염증 부위로 호중구를 유인하여 부종을 유발시키고, 급성 면역반응을 유도하는 인자이다(Zhang et al., 1992).

LPS는 대식세포에서 인터류킨류(interleukin)와 TNF $\alpha$, $\mathrm{iNOS}$ 등의 염증매개 인자의 생산을 촉진한다. 본 실험에서는
$100 \mathrm{ng} / \mathrm{mL}$ 농도의 LPS를 처리하여 대식세포의 염증반응을 유 도하였다. 본 연구에서 $\mathrm{GA}$ 추출물의 염증성 사이토카인의 감 소효과를 확인한 결과, $I L 1 \alpha$ 는 LPS 처리군에 의해 760 배 증가 하였으나 $50,25 \mu \mathrm{g} / \mathrm{mL}$ 의 GA 추출물을 처리하였을 때 각각 $69 \%, 36 \%$ 정도 발현이 감소하였다(Figure $5 \mathrm{~A}$ ). $I L 1 \beta$ 는 $50 \mu \mathrm{g} /$ $\mathrm{mL}$ 의 $\mathrm{GA}$ 추출물을 처리하였을 때 LPS 처리군에 비하여 $84 \%$ 정도 발현이 감소하였다(Figure 5B). IL6는 $50,25,5 \mu \mathrm{g} / \mathrm{mL}$ 의 GA 추출물을 처리하였을 때 LPS 처리군에 비하여 각각 $98 \%$, $86 \%, 43 \%$ 정도 발현이 감소하였다(Figure $5 \mathrm{C}$ ). $T N F \alpha$ 는 GA 추출물 $50 \mu \mathrm{g} / \mathrm{mL}$ 의 농도에서 LPS 처리군에 비해 $49 \%$ 정도 발 현이 감소하였다(Figure $5 \mathrm{D}$ ). 본 연구에서 $\mathrm{GA}$ 추출물이 염증에 관여하는 전사인자의 발현을 억제시켰으며, $\mathrm{NO}$ 와 $\mathrm{PGE} 2$ 의 생성 모두 농도 의존적으로 감소시킴을 통하여 항염증 효능을 확인하 였고, 염증성 질환 개선에 도움을 주는 기능성 화장품 원료로서 $\mathrm{GA}$ 추출물이 유용할 수 있음을 보여주는 기초적인 자료가 될 것 으로 사료된다.

\section{Conclusion}

피부는 노화에 의하여 주름이 생성되고 두꺼워지고 염증 등의 증상이 나타난다. 자외선과 미세먼지, 세균 등과 같은 외부환경 에 의해 피부는 활성산소종과 $\mathrm{NO}$ 의 연쇄 반응을 통해 노화가 촉 진되고 염증질환 등이 발생한다(Kim et al., 2011; Talwar et al., 1995). 또한 노화는 성체 내 존재하는 구성세포의 감소 혹 은 기능저하에 의해 정상적인 기능을 하는 조직으로서의 재생 및 

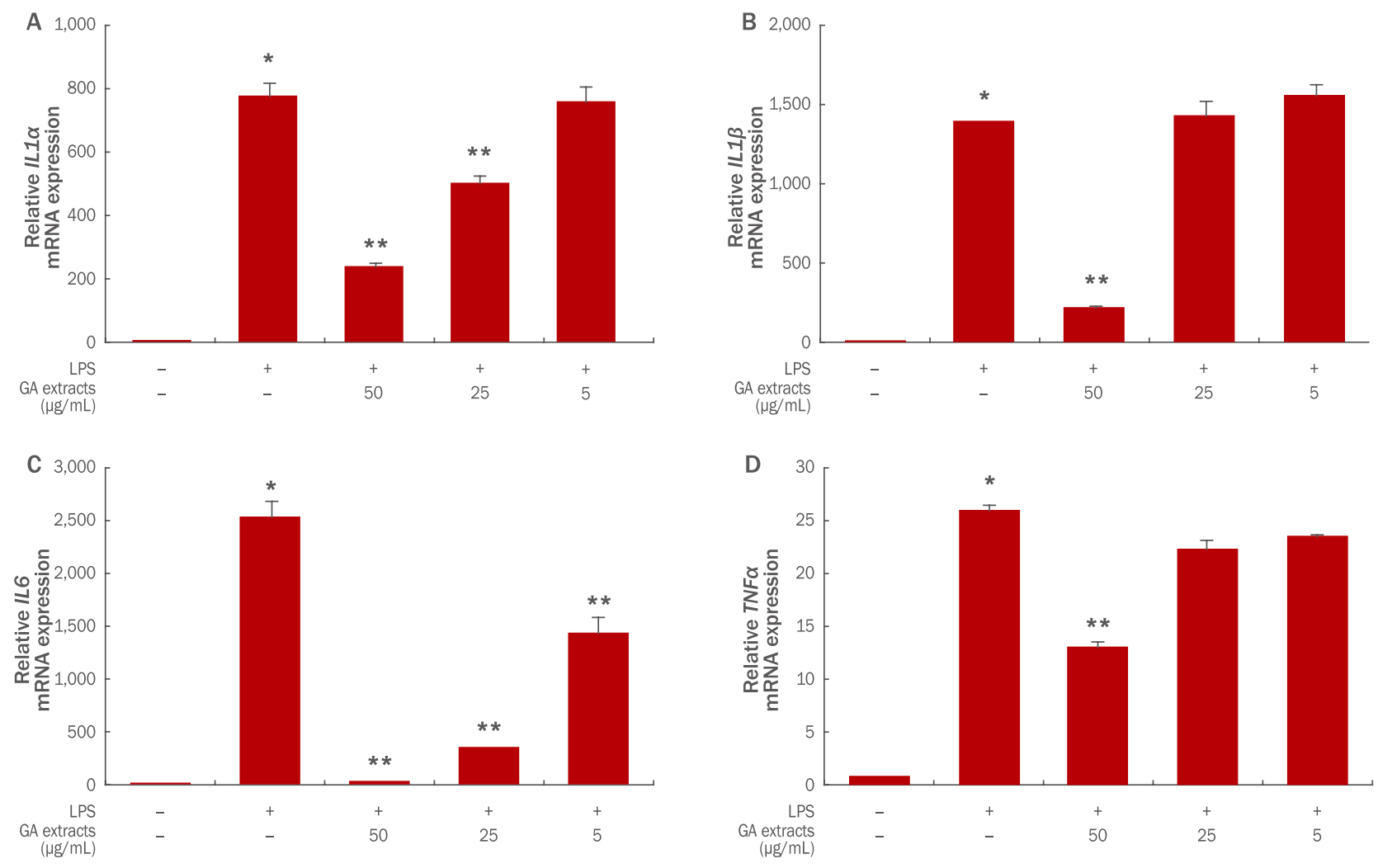

Figure 5. Effects of GA on the mRNA expressions of inflammatory cytokines.

qRT-PCR analysis of pro-inflammatory transcription factors, such as $I L 1 \alpha(\mathrm{A}), I L 1 \beta(\mathrm{B}), I L 6$ (C), and TNF $\alpha$ (D). The $50 \mu \mathrm{g} / \mathrm{mL} \mathrm{GA}$ extract decreased the expression of $I L 1 \alpha(69 \%)(A), I L 1 \beta(84 \%)(B), I L 6(98 \%)(C)$, and $T N F \alpha(49 \%)(D)$ compared with LPS-treatment. The graphs are shown as the $M \pm S . D$. of three independent experiments. $I L 1 \alpha$, interleukin 1 alpha; $I L 1 \beta$, interleukin 1 beta; IL6, interleukin 6 ; LPS, lipopolysaccharide; $T N F \alpha$, tumor necrosis factor $\alpha$; GA, Galium aparine; qRT-PCR, quantitative real-time polymerase chain reaction; ${ }^{*} p<0.05$ compared with control; ${ }^{* *} p<0.05$ compared with LPS-treated group; Cont, Control; M \pm S.D., means \pm standard deviations.

기능을 하지 못하게 된다(Jones \& Rando, 2011; Kirkwood et al., 2005).

본 연구에서 GA 추출물은 농도의존적으로 radical 소거능을 지닌 항산화 효능이 있음을 확인하였다(Figure 1). 또한 GA 추 출물을 RAW 264.7 대식세포에 처리할 적절한 농도를 확인할 수 있었다. $50 \mu \mathrm{g} / \mathrm{mL}$ 의 농도에서는 대식세포의 생존율에 영 향을 미치지 않음을 Figure 2에서 확인하였다. iNOS, COX2, $I L 1 \alpha, I L 1 \beta, I L 6$ 와 $T N F \alpha$ 의 유전자 발현 측정과 $\mathrm{NO}$ 생성량 측 정, PGE2 단백질 발현 측정에서 GA 추출물이 유의성 있게 LPS 에 의해 증가된 염증에 관여하는 인자의 발현이 회복되는 결과를 나타내었다(Figure 3-5), 이는 GA 추출물이 새로운 피부 염증 개선 후보 물질로서의 가능성을 보여준다.

$\mathrm{GA}$ 추출물의 피부 염증 개선 효과를 확인한 결과는 본 연구가 최초로, 추후 피부미용과 피부질환 치료제로서 실질적으로 활용 이 될 수 있고 염증에 의한 피부노화를 예방할 수 있는 가능성을 제시한 결과라 사료된다. 추가적으로 GA 추출물의 지표물질의 규명과 다양한 용매를 이용한 추출법으로 얻어지는 추출물의 비 교연구도 수행되어야 한다. 향후 GA 추출물이 어떠한 기전으로
LPS에 의해 염증이 유발된 피부를 개선하는지에 대해 추가연구 와 심도 있는 임상연구가 필요할 것으로 보인다.

\section{Acknowledgements}

I thank AJ Co., Ltd. (Asan, Korea) for supplying the plant material. This paper was supported by the Semyung University Research Grant of 2017.

\section{References}

Ahmad SS, Javed S. Exploring the economic value of underutilized plant species in ayubia national park. Pakistan Journal of Botany, 39: 1435-1442, 2007.

Akira S, Takeda K. Toll-like receptor signaling. Nature Reviews Immunology, 4: 499-511, 2004.

Albina JE, Reichner JS. Nitric oxide in inflammation and immunity. New Horizons, 3: 46-64, 1995. 
Baek YM, Choi JY, Lee CW, Jeon YS, Han JT, Jang SI, Yoo HS. Effects of Chinemys reevesii on lipopolysaccarideindused inflammatory reactions. Journal of Physiology \& Pathology in Korean Medicine, 26: 26-34, 2012.

Ban JY, Kim BS, Kim SC, Kim DH, Chung JH. Microarray analysis of gene expression profiles in response to treatment with melatonin in lipopolysaccharide activated RAW 264.7 cells. The Korean Journal of Physiology \& Pharmacology, 15: 23-29, 2011.

Bokhari J, Khan MR, Shabbir M, Rashid U, Jan S, Zai JA. Evaluation of diverse antioxidant activities of Galium aparine. Spectrochimica Acta Part A: Molecular and Biomolecular Spectroscopy, 102: 24-29, 2013.

Ergun F, Deliorman D, Velioglu A, Sener B. Antimicrobial activities of Galium species. Journal of Faculty of Pharmacy of Gazi University, 16: 7-11, 1999.

Gabay C. Interleukin-6 and chronic inflammation. Arthritis Research \& Therapy, 8: S3, 2006.

Gomez PF, Pilllinger MH, Attur M, Marjanovic N, Dave M, Park J, Bingham CO 3rd, Al-Mussawir H, Abramson SB. Resolution of inflammation: prostaglandin E2 dissociates nuclear trafficking of individual NF-kappaB subunits (p65, p50) in stimulated rheumatoid synovial fibroblasts. Journal of Immunology, 175: 6924-6930, 2005.

Harris SG, Padilla J, Koumas L, Ray D, Phipps RP. Prostaglandins as modulators of immunity. Trends in Immunology, 23: 144-150, 2002.

Hartwell JL. Plants used against cancer. a survey. Lloydia, 34: 386-425, 1971.

Heinzmann A, Daser A. Mouse models for the genetic dissection of atopy. International Archives of Allergy and Immunology, 127: 170-180, 2002.

Hirohashi N, Morrison DC. Low-dose lipopolysaccharide (LPS) pretreatment of mouse macrophages modulates LPSdependent interleukin- 6 production in vitro. Infection and Immunity, 64: 1011-1015, 1996.

Horwood NJ, Page TH, McDaid JP, Palmer CD, Campbell J, Mahon T, Brennan FM, Webster D, Foxwell BM. Bruton's tyrosine kinase is required for TLR2 and TLR4-induced TNF, but not IL-6, production. The Journal of Immunology, 176: 3635-3641, 2006.

Im DY. Volatile compounds analysis of the extract from dried bark of Prunus sargentii and physiological activity of the main compound, benzaldehyde. Asian Journal of Beauty and Cosmetology, 12: 155-162, 2014.

Jeong KS, Pak JH. A cytotaxonomic study of Galium (Rubiaceae) in Korea. Korean Journal of Plant Taxonomy, 39: 42-47, 2009.

Jones DL, Rando TA. Emerging models and paradigms for stem cell ageing. Nature Cell Biology, 13: 506-512, 2011.

Kim J, Lee CW, Kim EK, Lee SJ, Park NH, Kim HS, Kim HK, Char K, Jang YP, Kim JW. Inhibition effect of Gynura procumbens extract on UV-B-induced matrixmetalloproteinase expression in human dermal fibroblasts. Journal of Ethnopharmacology, 137: 427433, 2011.

Kim S, Kang BY, Cho SY, Sung DS, Chang HK, Yeom MH, Kim $\mathrm{DH}$, Sim YC, Lee YS. Compound $\mathrm{K}$ induces expression of hyaluronan synthase 2 gene in transformed human keratinocytes and increases hyaluronan in hairless mouse skin. Biochemical and Biophysical Research Communications, 316: 348-355, 2004.

Kirkwood TB. Understanding the odd science of aging. Cell, 120: 437-447, 2005.

Lawrence T, Willoughby DA, Gilroy DW. Anti-inflammatory lipid mediators and insights into the resolution of inflammation. Nature Reviews Immunology, 2: 787-795, 2002.

Lee HY, Kim KJ, Kim YS, Lee SN, Lee SO. Skin science, Gunja Publishing, Paju, pp20-24, 2007.

Lee HJ, Sim BY, Bak JW, Kim DH. Effect of Gami-sopungsan on inflammation and DNCB-induced dermatitis in NC/ Nga in mice. Journal of Physiology \& Pathology in Korean Medicine, 28: 146-153, 2014.

Lord PC, Wilmoth LM, Mizel SB, McCall CE. Expression of interleukin-1 alpha and beta genes by human blood polymorphonuclear leukocytes. The Journal of Clinical Investigation, 87: 1312-1321, 1991.

Namazi MR. Cetirizine and allopurinol as novel weapons against cellular autoimmune disorders. International Immunopharmacology, 4: 349-353, 2004.

Noman AS, Koide N, Hassan F, I-E-Khuda I, Dagvadorj J, Tumurkhuu G, Islam S, Naiki Y, Yoshida T, Yokochi T. Thalidomide inhibits lipopolysaccharide-induced tumor necrosis factor-alpha production via down-regulation of MyD88 expression. Innate Immunity, 15: 33-41, 2009. 
Orhan N, Deliorman Orhan D, Aslan M, Süküroğlu M, Orhan IE. UPLC-TOF-MS analysis of Galium spurium towards its neuroprotective and anticonvulsant activities. Journal of Ethnopharmacology, 141: 220-227, 2012.

Pryor WA. Free radical biology: xenobiotics, cancer, and aging. Annals of the New York Academy of Sciences, 393: 1-22, 1982.

Roitt I, Brostoff J, Male D. Immunology, 6th edition. Mosby, New York, pp119-441, 2001.

Shon MS, Song JH, Kim JS, Jang HD, Kim GN. Anti-oxidant activity of oil extracted from Korean red ginseng and its moisturizing function. Asian Journal of Beauty and Cosmetology, 11: 489-494, 2013.

Sung YY, Kim DS, Yang WK, Nho KJ, Seo HS, Kim YS, Kim HK. Inhibitory effects of Drynaria fortunei extract on house dust mite antigen-induced atopic dermatitis in NC/Nga mice. Journal of Ethnopharmacology, 144: 94100, 2012.

Talwar HS, Griffiths CE, Fisher GJ, Hamilton TA, Voorhees JJ. Reduced type I and type III procollagens in photodamaged adult human skin. Journal of Investigative Dermatology, 105: 285-290, 1995.

Van Triel JJ, Arts JH, Muijser H, Kuper CF. Allergic inflammation in the upper respiratory tract of the rat upon repeated inhalation exposure to the contact allergen dinitrochlorobenzene (DNCB). Toxicology, 269: 73-80, 2010.

Yoon Y, Bae S, An S, Choe YB, Ahn KJ, An IS. Effects of ultraviolet radiation on the skin and skin cell signaling pathways. Asian Journal of Beauty and Cosmetology, 11: 417-426, 2013.

Yun KJ, Kim JY, Kim JB, Lee KW, Jeong SY, Park HJ, Jung HJ, Cho YW, Yun KJ, Lee KT. Inhibition of LPS-induced NO and PGE2 production by asiatic acid via NFkappa B inactivation in RAW 264.7 macrophages: possible involvement of the IKK and MAPK pathways. International Immunopharmacology, 8: 431-441, 2008.

Zhang Y, Ramos BF, Jakschik BA. Neutrophil recruitment by tumor necrosis factor from mast cells in immune complex peritonitis. Science, 258: 1957-1959, 1992. 


\section{국문초록}

\section{갈퀴덩굴 추출물에 의한 RAW 264.7 세포에서의 항염 효과}

심중현

세명대학교 화장품·뷰티생명공학부, 충청북도 제천시, 한국

목적: 본 연구는 lipopolysaccharide (LPS)에 의해 염증이 유도된 RAW 264.7 세포에서 갈퀴덩굴(Galium aparine, GA) 추출물의 염증억제 효과를 확인하기 위하여 수행되었다. 방법: GA 추출물이 RAW 264.7 세포에서 항염 효과를 나타내는지 확인하기 위하여 1,1-diphenyl-2-picrylhydrazyl (DPPH) radical 소거 활성, GA 추출물의 세포 생존율 측정, 사이토카인의 발현양상, nitric oxide (NO)와 prostaglandin $\mathrm{E} 2$ (PGE2)의 생성 정도를 확인하였다. 결과: GA 추출물이 interleukin $1 \alpha(\mathrm{IL} 1 \alpha)$, interleukin $1 \beta$ (IL1ß), interleukin 6 (IL6), tumor necrosis factor $\alpha(T N F \alpha)$ 유전자 발현을 감소시킴을 확인할 수 있었다. 또한 NO 생성을 감소시키고 $\mathrm{PGE} 2$ 단백질 생성을 감소시킴을 통해 GA 추출물의 항염 효과를 확인할 수 있었다. 결론: 본 연구를 통해 GA 추출물의 항염 효과 를 확인하였고, GA 추출물이 항염 및 아토피를 타겟으로 하는 화장품 원료로서의 가능성을 제시하였다. 앞으로 $\mathrm{GA}$ 추출물이 피부 미용, 의약품 산업 등에도 응용될 수 있을 것으로 여겨지며 그 가능성을 확인하기 위해 $\mathrm{GA}$ 추출물이 염증세포에 미치는 기전 연구 가 필요할 것으로 보인다.

핵심어: 갈퀴덩굴, 라디칼 소거능, 항염, 산화질소, $\mathrm{PGE} 2$

I thank AJ Co., Ltd. (Asan, Korea) for supplying the plant material. This paper was supported by the Semyung University Research Grant of 2017.

\section{참고문헌}

백영미, 최정은, 이철우, 전영식, 한진택, 장성일, 유화승. 구판의 LPS로 유도된 염증 반응 억제 효과. 동의생리병리학회 지, 26: 26-34, 2012.

손명수, 송지혜, 김종식, 장해동, 김교남. 홍삼에서 추출한 오일의 항산화 및 보습활성. 아시안뷰티화장품학술지, 11 : 489-494, 2013.

윤영민, 배승희, 안성관, 최용범, 안규중, 안인숙. 자외선(Ultraviolet)이 피부 및 피부세포 내 신호전달체계에 미치는 영

향. 아시안뷰티화장품학술지, 11: 417-426, 2013.

이혜영, 김귀정, 김영순, 이성내, 이성옥. 피부과학, 군자출판사, 파주, pp20-24, 2007.

이해진, 심부용, 박지원, 김동희. 加味消風散이 염증 및 아토피피부염 동물병태에 미치는 영향. 동의생리병리학회지, 28 : 146-153, 2014.

임도연. 화피의 휘발성 향기성분 조성과 주요성분인 Benzaldehyde의 생리활성. 아시안뷰티화장품학술지, $12: 155-162$, 2014.

정금선, 박재홍. 한국산 갈퀴덩굴속(Galium L.)의 세포분류학적 연구. 식물 분류학회지, 39: 42-47, 2009. 


\section{中文摘要}

\section{猪殊殊提取物在RAW 264.7细胞中的抗炎作用}

\section{沁重鉉}

世明大学化妆品·美容生命工学科，忠清北道提川市，韩国

目的: 探索lipopolysaccharide（LPS）诱导炎症的RAW 264.7细胞中, 猪殊殊（Galium aparine，GA）提取 物的炎症抑制效果。方法: 为确认GA对RAW 264.7细胞的抗炎作用, 测量了1,1-diphenyl-2-picrylhydrazyl (DPPH) 自由基清除活性, 细胞存活率, mRNA表达,一氧化氮（nitric oxide，NO）和前列腺素E2 (prostaglandin E2, PGE2) 的生成程度。结果: GA提取物可降低白细胞介素1a（interleukin 1a, IL1 $\alpha$ ), 白介 素1 $\beta$ （interleukin $1 \beta, I L 1 \beta$ ), 白细胞介素6（interleukin 6,IL6）和肿瘤坏死因子 $\alpha$ (tumor necrosis factor $\alpha, T N F \alpha) m R N A$ 的表达。此外, 通过减少NO和PGE2蛋白质的生成, 证实了GA提取物的抗炎作用。结论: 本 研究证实了GA提取物的抗炎作用, 并提出了GA提取物作为化妆品原料抗炎和抗过敏的可能性。未来, GA提取 物被认为可用于皮肤化妆品, 制药工业等, 为了证实这种可能性, 有必要研究GA提取物对炎症细胞的作用机 制。

关键词: 猪殊殊，自由基消除能，抗炎，一氧化氮，前列腺素E2 